\title{
To Learn to Revive: The Lessons of Chinese 500 Years' Falling and Re-Rising History
}

\author{
Xiaodong Li, Yuzhong Du \\ School of Marxism, Beijing Jiaotong University, Beijing, China \\ Email: xdli@bjtu.edu.cn
}

How to cite this paper: Li, X. D., \& $\mathrm{Du}, \mathrm{Y}$. Z. (2021). To Learn to Revive: The Lessons of Chinese 500 Years' Falling and Re-Rising History. Chinese Studies, 10, 53-68.

https://doi.org/10.4236/chnstd.2021.101005

Received: January 15, 2021

Accepted: February 16, 2021

Published: February 19, 2021

Copyright (c) 2021 by author(s) and Scientific Research Publishing Inc. This work is licensed under the Creative Commons Attribution International License (CC BY 4.0).

http://creativecommons.org/licenses/by/4.0/ (c) (i) Open Access

\begin{abstract}
500 years ago, the Western Europe began its great voyage and grand rise, meanwhile China fell into its impact-response model with the West after ending Zhenghe's voyage to the Western seas, which to be exact is the western learning's east-forward expanding. After failed efforts of learning the Western mainstream democracy-science, China departed from the road of westernization and turned to Marxism's Sinicization, which made a new China stand up to shook the world. However to lean to the socialism side against capitalism did not succeed enough to build an even more modernized China than Euro-American imperialism, therefore China decided to learn the western capitalism one more time, but this time focusing on how-toes and sciences and technologies for economy rather than democracy for the statecraft, which makes China the second economy and shakes the world second time. But for China, to learn from the West and to rejuvenate itself are two wings for flying high and long, which is the lessons from Chinese 500 years' falling and re-rising history.
\end{abstract}

\section{Keywords}

West, China, Learn, Revive, Lesson

\section{Introduction}

People usually divide the world into the democratic West and the authoritarian East, and concern about losing in the clash of civilization (Huntington, 2011) or the destined war (Allison, 2018), even when it has come to a single pandemic world. "The virus is a wake-up call", Micklethwait and Wooldridge warned, "if we ignore the wake-up call, or hit the snooze button, a Sino-centric world beckons, with the United States becoming a large offshore island, while Europe returns to what it was five centuries ago, an archipelago at the poorer, western end of Eura- 
sia" (Micklethwait, Wooldridge, Via, \& Virginia, 2020: pp. 10-11). Surely, over the last 500 years, the world's evolution led the Dutch empire to rise and decline into the British Empire, the British Empire to rise and decline into the US Empire, and the US Empire to rise and enter its early decline into the rise of the Chinese empire (Dalio, 2020). In June 2018, China's president Xi Jinping pointed out at the Central Foreign Affairs Work Conference that the world is undergoing major changes unseen in centuries. Earlier, in his speech at the celebration of the 95th anniversary of the founding of the Communist Party of China, he claimed that the great victories achieved by the Chinese people under the leadership of the Communist Party of China have enabled the 500-year-old socialist proposition to successfully open up a correct path that has a high degree of reality and feasibility in the world's most populous country, giving scientific socialism new vigor in the 21st Century. Harvard University professor Graham Allison suggested focusing on the lessons from the history when confronting with historical changes, but different history teaches different lessons. When he chose Sparta and Athens, he fell into Thucydides's trap, which is none other than his construction. China and America are not like Sparta and Athens, or German and Briton, it is like Soviet and America, or UK and USA, by which we can learn that the keeping powers lost dominant power or collapse when they can't learn from the rising powers to revive themselves. In the history, there was never a super power which was knocked out by a rising power, and a rising super never chose to fight a war with a keeping power, but rather wait for the destiny. Yes, as Ray Dalio said all super powers like human beings had their lifetime, so what is destined for is not war but rise and fall. However, while nearly all the super powers never rise again after fall, with Macedonia, Persia, Rome, Mongolia and Osman as old example, with Briton and Soviet as not so exact but near example, some others may revive, with China as the most specific example since it has fallen and re-risen again and again. Chinese prefer comedies much better to tragedies, Chinese historian, living tragic life himself, usually wrote comic history for good governance, like Si Maguang's General History for Good Governance, most importantly for the revival of the flourishing age, like Confucius's Compilation of Lu's history with the title Spring and Autumn for the revival of Zhou. The following is the 500 years of world history, with China's fall and revive, which will teach different lessons from Greece's fall but no coming re-rise again to date.

\section{The Rise of the Capitalism Europe and the Western Learning's Import in the East}

During the course of the thousands of years of scrutable, written human history, China in the East and the West were in leading positions for a long time. The rise of the West was accompanied by great navigation, revolution, and the rise of capitalism that began at the end of the 15th Century. The decline of China was also accompanied by the maritime prohibition, closure, and extreme feudal autocracy that began at the end of the 15th century. In 1984, in his speech at the third plenary meeting of the Central Advisory Committee, Deng Xiaoping pointed 
out that "from the middle of the Ming Dynasty, China had more than 300 years of being closed off until the Opium War" which "made China poor, backward, and ignorant" (Deng, 1993: p. 90).

In 1492, Christopher Columbus set off from Spain across the Atlantic and returned the following year, thus heralding a new era in world history (Goldstone, 2010: p. 5). Around 1500 to around 1800 was a breakthrough stage in the development of capitalism, and what Marx and Weber called "modern capitalism" was born (Kocka, 2017: p. 26). Traditional regional autonomy began to yield to global unity when Western overseas expansion began about 1500. Since the Europeans took the lead in this global activity, it was they who dominated the newly integrated world. By the 19th century, they controlled the world politically and economically with their powerful empires and stock companies (Stavirianos, 2004: p. 396). After 1433, China ended Zheng He's grand voyages to the West, and was busy resolving ethnic conflicts in its northern lands. After the fall of the Ming Dynasty, the Qing Dynasty imposed stricter maritime bans in order to isolate the mainland and Taiwan from anti-Qing forces. The ancient feudal empire seemed to have ushered in unity and prosperity again, but it was in fact moving towards a more closed and rigid phase, meaning it was a phase of prosperity and decline. However, the West had opened up a vast space for development because of its great voyages, and human history advanced to a new stage of capitalism.

Marx and Engels pointed out in "The Communist Manifesto": "The discovery of America, the rounding of the Cape, opened up fresh ground for the rising bourgeoisie. The East-Indian and Chinese markets, the colonization of America, trade with the colonies, the increase in the means of exchange and in commodities generally, gave to commerce, to navigation, to industry, an impulse never before known, and thereby, to the revolutionary element in the tottering feudal society, a rapid development." (Marx and Engles, 1995: p. 273) The huge impact brought about by this great navigation was that Europe gained a vast world market, which also created business models and then the transformation of industrial production methods. The West created a modern capitalist civilization that transformed itself and conquered the world, but China was still languishing in the complacency and arrogance of feudal empire. The Western bourgeoisie would not be enough to maintain the prosperity of capitalism unless it entered the Chinese market. After failed attempts to open the hearts and desires of the Chinese people with daily commodities, the British chose to poison their bodies and spirits with opium. After that, Sino-British trade gradually underwent a reversal in favor of Britain, with large amounts of silver flowing there. Lin Zexu was ordered to implement an anti-smoking campaign to oppose the uncivilized poisoning of the British, but the British then resolved to use warfare to destroy the Chinese will to resist. In 1840, British artillery blasted open the southern gate of China, and Western ships and artillery completely destroyed China's coastal defenses. Thereafter, as Marx and Engels pointed out in "The Communist Manifesto", the bourgeoisie "subordinated the East to the West." (Marx and Engles, 1995: p. 276). 
In May 1872, Li Hongzhang reconsidered that the ships could not be dismantled and said: "I have thought privately about the European countries. Over the past 100 hundred years, they have expanded from India to Southeast Asia, and from Southeast Asia to China, and then invaded the hinterlands of China. Nothing of that sort has been recorded in the history books. People in ancient times did not have to be flexible as there was nothing more than foreigners clearing borders to request mutual trade. Our emperor thought about the situation comprehensively and set up contracts with them to conduct business with them and contain them, so that the wealth of the 90,000 miles of land in the east, west, north and south of the earth can be gathered in China. This is a huge change from the past 3000 years." (Liang, 2017: pp. 61-62) In 1875, due to the Taiwan Incident, he said in a Memorial to the Throne for the Coastal Denfence Plan: "The frontiers of the past are mostly in the northwest." "Today, there are than tens of thousands of miles in the southeast coast. All countries trade and preach and travel freely. They gather in the capital and the hinterland of the provinces. Devouring insidiously, one country creates things, and several countries instigate it. It is a change that has not been seen in thousands of years!” (Liang, 2017: pp. 62-63). The so-called "big change in more than 3000 years" and "change that has not occurred in thousands of years" were the impacts of ocean civilization on land civilization and capitalism on feudalism.

The Opium War was not only the beginning of China's "century of humiliation" history, but also the beginning of China's "road to rejuvenation." From then on, Western science and technology began to shake the hearts of Chinese people, and Western culture opened the process of "the eastward transmission of western sciences". During this process, the Chinese people never forgot the pain they suffered from Western aggression, and tried to learn from the achievements of advanced civilization while surpassing the barbaric aggression of the West so as to realize the revival of the Chinese nation and the excellent and traditional Chinese culture.

The Taiping Heavenly Kingdom Movement led by Hong Xiuquan was first "anti-Qing", but it also wanted to pursue prosperity for China. In the later period, Hong Xiuquan's younger brother, Hong Rengan, who served as the prime minister of the Taiping Heavenly Kingdom, proposed "A New Chapter of Capital and Politics". The central idea was to study the political systems and science and technology of Western countries. Zeng Guofan's “Discussing Thieves” accused the Taiping Rebels of "stealing the traditions of foreign barbarians and admiring the teachings of God", "the scholars cannot recite the scriptures of Confucius, and have had the so-called the book of the "New Testament" of Jesus since its inception, a great change in religion". (Qian, 1996: pp. 878-879). Obviously, Zeng Guofan organized various forces to oppose the Taiping Heavenly Kingdom with the call to safeguard Chinese Confucianism. Conversely, the lack of local cultural roots in the guiding ideology of the Taiping Heavenly Kingdom was obviously an important reason for its failure. People's evaluation of Zeng 
Guofan has improved, mainly because of his contribution to traditional Chinese culture. In May 1872, Li Hongzhang reconsidered that the manufacture of ships could not be abolished and said: "The Westerners rely on the superiority of their guns and ships, so they can run rampant in China. The equipment used by China is inferior to them, so China is controlled by Western people." (Liang, 2017: p. 62). This was the self-improvement movement proposed by the Westernization School to learn from the Western military industry, which later further developed to learning from Western capitalist industry and commerce, and from this, China's earliest capitalist industry and commerce enterprises were created.

After the failure of the Westernization Movement, the Chinese learned from the West from the level of artifacts to the level of political systems and science and culture, and the goal of industrialization gradually became the task of private entrepreneurs. The Hundred Days Reform was an effort to learn from Western constitutional monarchies like Japan, but it was quickly nipped in the bud by the conservatives of the Qing government headed by the Empress Dowager Cixi. In the end, the fruits of the Hundred Days Reform left only the start of modern education, which is today's Peking University, called Jingshi University at the time, and the development of a small amount of modern science and technology such as postal services, railways, telegraphs, and hospitals. The Revolution of 1911 led by Sun Yat-sen wanted to learn from the democratic republics in the West. However, because the old bureaucrats represented by Yuan Shikai controlled the army, the Republic of China had only one sign left in the end, and China fell into a more tragic situation of warlord separatism and imperialism. Many people think this was because of problems in Chinese culture, so a new cultural movement emerged, mainly under the leadership of intellectuals who had returned from studying abroad. Its goal was to "knock down Confucianism" and hold high the two flags of "Mr. De" and "Mr. Sai", which was to abandon traditional culture and replace it with Western bourgeois democracy and modern science.

In fact, the New Culture Movement completely rejected traditional Chinese culture, and was a reform plan for the complete westernization of the economy, politics, society and culture. China had reached its most desperate moment, but this was the darkness before the dawn.

In 1919, Britain and France led the Paris Peace Conference and decided to transfer the rights and interests of the defeated Germany in Shandong to Japan, and the Chinese people finally realized how hypocritical the so-called "national self-determination" principle of bourgeois "democracy" was. It was impossible to expect capitalist countries to obtain national self-determination and democratic politics. Chinese people could only fight for national independence and people's democracy by themselves. Many people turned their eyes to Russia after the October Revolution of 1917 and decided to learn from Russia and take the road of proletarian revolution. The Communist Party of China was established in 1921. Since then, the Chinese working class has had its own vanguard, and the 
Chinese peasants had gained a powerful force to lead them.

The outstanding feature of the Russian Revolution was its reliance on the power of workers and peasants, which also greatly inspired Sun Yat-sen, who was unable to find a powerful force to rely on for the revolution. On the basis of gathering together the lessons of the revolution and with the help of the Chinese Communist Party, he decided to change his political line of relying mainly on bourgeois financial aid, relying on the armed forces of warlords, and relying on the revolutionary enthusiasm of young students to learning from the Russian revolution to mobilize workers and peasants. In order to implement the new revolutionary line, Sun Yat-sen also decided to reform the Kuomintang in accordance with the Soviet model, establish a military school and establish an independent revolutionary armed forces. Soviet Russia sent Mikhail Borodin to assist Sun Yatsen in reorganizing the Kuomintang, and also sent Adolph Joffe to assist Sun Yatsen in establishing the Huangpu Military Academy. On January 20, 1924, the First National Congress of the Chinese Kuomintang was held in Guangzhou. The congress determined the three major policies of "Alliance with Russia, Alliance with the Communist Party, and Helping Peasants and Workers" and reinterpreted the Three Principles of the People. The nationalism of the new Three Principles of the People was transformed from an anti-feudalist principle of "removing the Tartars and restoring China" to uniting the entire Chinese nation against imperialism.

On June 30, 1949, Mao Zedong pointed out in his speech to commemorate the 28th anniversary of the founding of the Communist Party of China that ever since their defeat in the Opium War of 1840, the advanced Chinese people, after untold hardships, were seeking the truth from Western countries. Hong Xiuquan, Kang Youwei, Yan Fu, and Sun Yat-sen represented a group of figures who sought truth from the West before the Communist Party of China was born. However, their imperialist aggression broke the pipe dream of the Chinese people of learning from the West. In the end, the Chinese found the universal truth of Marxism-Leninism, and the face of China changed (Mao, 1991: pp. 1469-1470).

In short, around 1500, Europeans began the era of great navigation and the industrial revolution. In the following 300 years, Western society developed twice as fast as Eastern society, which eventually led to Western society overtaking the East, ending the 1200-year Eastern era (Morris, 2014: p. 277). In this process, not only did capitalism begin springing up in Europe, it also carried out imperialist aggression and expansion worldwide, establishing colonies all over the world. However, in addition to the peak of feudalism and the rise of capitalism, a brandnew social system in human history, socialism, had also moved from an idle dream to science in this process, and China therefore had a brand new choice available for realizing national rejuvenation.

\section{China Turned to Communism Soviet and Succeeded Its Strategy of Sinicization}

Mao Zedong pointed out that the outbreak of the First World War and the October Revolution in Russia marked that capitalism was "different from the pro- 
gressive era of capitalism when Britain destroyed India" and "was in a period of regression." (Mao, 1991: p. 451). A new era of the people of the colonies opposing imperialism and feudalism had arrived, as well as the era of the proletariat leading the socialist revolution. The Second World War "occurred on the basis of the development of the general crisis of world capitalism that had already begun in the First World War." "We can foresee that the outcome of this war will not be the rescue of capitalism, but it's heading for collapse", "the liberation of the Chinese nation will come from this war.” (Mao, 1991: p. 475). However, just like the Hundred Days' Reform that learned from the Meiji Restoration of Japan and the Xinhai Revolution of 1911 that learned from the American Democratic Revolution, because of the obvious copying of the experiences of other countries, China's destiny was not fundamentally changed. The proletarian revolution, which replicated the experiences of the Soviet Union, also found it difficult to change China's fate.

Marx keenly pointed out that "philosophers just interpret the world in different ways, and the problem lies in changing the world." (Marx and Engles, 1995: p. 140). The fundamental reason why Marxism is science, and the reason why socialism can realize the development of science from fantasy is adherence to "the theoretical principles of the people of the Communist Party, and never based on the ideas and principles invented or discovered by this or that world reformer." (Marx and Engles, 1995: p. 413). "The actual application of these principles, as stated in 'The Manifesto', must be subject to the historical conditions of the time at any time and place." (Marx and Engles, 1995: p. 386). Combining Marxism with China's historical conditions at that time, and putting forward practical and feasible methods to solve the problems of the Chinese revolution, and fundamentally change China's destiny, is in line with China's actual Sinicized Marxism.

Without the Sanitization of Marxism, there would be no Mao Zedong Thought and no victory for the Chinese revolution. In 1949, Mao Zedong pointed out in the article "The Bankruptcy of the Idealist Conception of History": "Any thought, if it is not connected with objective, practical things, if there is no need for objective existence, if it is not controlled by the masses, even the best things, even Marxism-Leninism, will not work" (Mao, 1991: p. 1515). On August 24, 1956, in a conversation with musicians, Mao Zedong said with emotion: "We must oppose dogmatism. We have suffered a lot in politics. We learned everything from Russia, treated it as dogma and the result was a big failure. The elimination of almost $100 \%$ of the white areas and $90 \%$ of the base areas and the Red Army delayed the victory of the revolution for many years. This is because they did not proceed from reality but rather from dogma. The dogmatists did not integrate the basic principles of Marxism-Leninism with the reality of the Chinese revolution." (Mao, 1999: p. 79).

It was precisely relying on his own thinking that Mao Zedong pioneered the success of the Chinese revolution in which the countryside encircled the cities and political power was seized by arms. As Deng Xiaoping pointed out, "Marx 
and Lenin never said that the countryside encircled the cities. This principle was not available in the world at that time. However, Comrade Mao Zedong pointed out the specific road of revolution based on China's specific conditions. When the warlords were divided, they led the people to establish revolutionary base areas in areas where the enemy's control was weak, surrounded the cities with rural areas, and finally seized political power." (Deng, 1993: p. 126). The Sinicization of Marxism was the basis for the victory of the Chinese Communists. "If we are not Marxists, do not have sufficient faith in Marxism, or we do not integrate Marxism with China's reality and follow our own path, the Chinese revolution will be unsuccessful." (Deng, 1993: pp. 62-63).

The success of the Chinese Communist Party's leadership of the new democratic revolution means that "Western bourgeois civilization, bourgeois democracy, and the plans of the bourgeois republics have all gone bankrupt in the eyes of the Chinese people. Bourgeois democracy gave way to the people's democratic bourgeois republic led by the working class to the people's republic. This creates a possibility of achieving socialism and communism through the people's republic, achieving class elimination and world unity." (Mao, 1991: p. 1471). From then on, China will not only advance along a development path different from that of Western capitalist countries, and keep pace with Western capitalist countries on the new path, and achieve sovereign independence and equality in the exchanges between China and Western countries.

On September 21, 1949, Mao Zedong's opening speech at the first plenary session of the Chinese People's Political Consultative Conference said: "Gentlemen, we have a common feeling that our work will be written into the history of mankind. It will show that the Chinese, who account for a quarter of the total number of human beings, have stood up... Our nation will no longer be an insulted nation. We have stood up." (Mao, 1999: p. 343). In his book "China Shakes the World", American war correspondent Jack Belden believed that the PLA's shelling of the British warship Amethyst in 1949 marked the end of an old era and the beginning of a new era. He said: "For nearly a hundred years foreign warships have been allowed to cruise down the lower reaches of the Yangtze River. No Chinese government was able to prevent them from entering and exiting, and no Chinese government was willing to do this." "Thirty years ago, as long as a British warship appeared on the Yangtze River, it was enough to temporarily change the situation of the Chinese Civil War"; "The People's Liberation Army crossed the Yangtze River and announced the end of a historical period. The period of gunboat diplomacy was gone forever. The opening of trade ports, the establishment of concessions, the lease of naval bases, the dispatching of troops to China, and openly interfering in China's internal affairs was gone forever." (Belden, 1980: pp. 323-324). The Chinese had been defeated by the British ships and guns. When the Chinese dared to fire at the British warships, the Chinese had indeed stood up!

The War to Resist US Aggression and Aid Korea was the first major war after the founding of New China. At that time, China was devastated by the destruc- 
tion of the war for a long time, and the enemy it faced was the so-called "United Nations Command", brought together by the world's most powerful country, the United States." This war finally ended with the signing of an armistice agreement. It at least let the powers of the world see that China was no longer a country to be bullied. Even the United States, being the most powerful country in the world, could not defeat China, and would have to pay an extremely heavy price to wage war against China and it would never be possible to win. This was the most direct meaning of "the Chinese people have stood up". Compared with the century of humiliation since the Opium War, this was a great historical change!

By the 1960s, the Chinese possessed atomic bombs, and the era of nuclear threats by the United States and the Soviet Union against China had passed! In 1971, China resumed its permanent membership of the United Nations. Since then, China and Western developed countries have also resumed formal international exchanges. China had truly stood up like a giant in the East! Of course, the Chinese Communist Party members are very clear, "To win a nationwide victory is just the first step in the Long March" and "After the revolution, the journey will be longer, the work will be greater, and the work will be more difficult.” (Mao, 1991: p. 1438).

On March 5, 1949, Mao Zedong confidently declared to the world in his report at the Second Plenary Session of the Seventh Central Committee of the Communist Party of China: "We are not only good at destroying an old world, we will also be good at building a new world. Not only can the Chinese people survive without begging the imperialists, but they will also live better than the imperialist countries." (Mao, 1991: p. 1439). On June 15, 1949, Mao Zedong's speech at the preparatory meeting of the New Political Consultative Conference said: "China's destiny is already being determined by its people. China will be like the sun rising in the east, illuminating the earth with its own glorious flames, quickly washing away the muddy water left by the reactionary government, healing the wounds of war, and building a new, strong, veritable people's republic." (Mao, 1991: p. 1467). On September 21, 1949, Chairman Mao clearly stated in his opening speech at the first plenary session of the Chinese People's Political Consultative Conference that a prosperous and civilized country should be built. He said: "The era of the Chinese people being considered uncivilized is over. We will appear in the world as a nation with a high level of culture." (Mao, 1999: p. 345). How eager the Chinese Communists were to build a prosperous and strong China!

In June 1954, Mao Zedong pointed out in his speech at the 30th meeting of the Central People's Government Committee: "Our overall goal is to strive for the building of a great socialist country. We are a big country with a population of 600 million. Realization of socialist industrialization requires the socialization and mechanization of agriculture." (Mao, 1999: p. 329). On October 29, 1955, Mao Zedong clearly stated in his speech at the symposium on the socialist transformation of capitalist industry and commerce that "our goal is to catch up with and surpass the United States." (Mao, 1999: p. 500). The implementation of the first five-year plan began in 1953. In the plan, the construction of industrial 
projects focusing on "156 items" was deployed, which fundamentally changed the backwardness of the old Chinese industry and enabled China to initially establish a relatively complete national economic system and industrial system.

Mao Zedong said, "Ten thousand years is too long. We must seize the day." It was the common aspiration of the Chinese people to get rid of the destiny of backwardness and beatings and build a prosperous and powerful civilization. It was also the national psychology of launching the "Great Leap Forward". On August 30, 1956, in Mao Zedong's speech at the first meeting of the preparatory meeting of the Eighth National Congress of the Communist Party of China, "Our country is built to be a great socialist country that will completely change the past 100 years of lagging behind, being looked down upon by others, misfortune, and will catch up with the most powerful capitalist country in the world, that is, the United States"; "If after 50 or 60 years, we still cannot surpass the United States, how could we live with ourselves? Then you have to expel your membership from the earth"; "If this is not the case, then our Chinese nation will be sorry to the nations of the world, and our contribution to mankind will not be so great." (Mao, 1999: p. 89). To surpass the United States to become a world-class country was the historical complex, moral sentiment, and world sentiment that Chinese people generally had at that time. On December 30, 1964, Mao Zedong added a paragraph when reviewing Zhou Enlai's draft government work report at the first meeting of the Third National People's Congress: "We cannot follow the old path of technological development in countries around the world and follow others crawling step by step in the future. We must break the conventions, use advanced technology as much as possible, and build our country into a socialist modernized power within a not too long historical period. This is what we mean by the Great Leap Forward." (Mao, 1999: pp. 341-342).

There is no doubt that the "Great Leap Forward" movement brought seriousness in the end, and the "Cultural Revolution" was even more of a catastrophe. However, as Deng Xiaoping said, "After the founding of the People's Republic of China, our economic construction has achieved great results. We have established a relatively complete industrial system and trained a group of technical talents." (Deng, 1993: p. 163). "The socialist revolution has allowed us to greatly decrease the gap between the country's economic development level and that of developed capitalist countries." "Despite some mistakes, we have made progress in the past 30 years that old China did not achieve in hundreds or thousands of years"; (Deng, 1993: p. 167) "For 30 years, no matter how many stupid things we have done, we have after all laid a preliminary foundation in industry, agriculture and technology, that is to say, we have a position from which we can advance towards the four modernizations." (Deng, 1993: p. 232).

\section{China Returned to the West for Market Economy and Re-Rose in the World}

The Third Plenary Session of the Eleventh Party Central Committee was convened, "it is the beginning of a new historical development stage." (Deng, 1993: 
p. 159). The main task of this historical period is to carry out socialist modernization. Modernization is a completely new undertaking that is completely different from revolution. Just as the Chinese revolution must integrate revolutionary theory with China's reality and take a revolutionary path that conforms to China's reality, China's modernization must also integrate modernization theory with China's reality and walk a path towards modernization that conforms with China's reality. Deng Xiaoping clearly pointed out that "democratic revolution in the past must suit China's conditions and follow the road of rural villages encircling towns that Comrade Mao Zedong pioneered. Now construction must suit China's conditions and follow a path of Chinese-style modernization." (Deng, 1993: p. 163). Take a society with Chinese characteristics. It can be said that China's modernization path and the exploration of the modernization plan are the goals set from the beginning of China's modernization drive and the fundamental guarantees for the great achievements of China's modernization drive.

When Deng Xiaoping met with Japanese Prime Minister Masayoshi Ohira in 1979, Deng Xiaoping made it clear: “The four modernizations were determined by Chairman Mao and Premier Zhou while they were alive. The so-called four modernizations are to change the face of poverty and backwardness in China, and not only make people's living standards gradually improve, they must also enable China to restore itself to a status that suits itself in international affairs and make more contributions to mankind.” (Deng, 1993: p. 237). In this meeting, he also made it clear that the modernization that China was to achieve at the end of the 20th Century would be "Chinese-style modernization." That is, "a well-off home." Deng Xiaoping put forward in 1980, "We are carrying out socialist modernization to catch up with the developed capitalist countries economically, and create a higher and more practical democracy than the capitalist countries' democracy politically, and create more and better talents than these countries." (Deng, 1993: p. 322). He put forward the strategic concept of dividing the 20 years at the end of the 20th Century into two decades. The first decade was to be about putting in the proper foundations and the next decade was to be about the strategic conception of "realizing the four modernizations of Chinese style" (Deng, 1993: p. 241). On April 26, 1987, when Deng Xiaoping met with the Prime Minister of Czechoslovakia, China's goal was to quadruple itself in 20 years from 1981 to achieve a well-off society. On this basis, it will take another 50 years to quadruple again and reach the level of a moderately developed country. Achieving this goal "not only found a way out for the Third World, which accounts for three-quarters of the world's total population, but more importantly, it showed mankind that socialism is the only way and that socialism is superior to capitalism.” (Deng, 1993: p. 225). Obviously, China has not only achieved the strategic goal of clarifying socialist modernization, it has also clearly proposed that China's socialist modernization plan being different from capitalist modernization should be explored.

Since Reform and Opening Up, China has maintained a miraculous economic 
growth rate in history, and the gap in overall national strength between China and developed Western capitalist countries has been continuously narrowing. In 2009, China's economic aggregate surpassed Japan to reach the second largest in the world, and the prediction that China's economic aggregate will surpass the United States has become a trend. On this basis, China has become the "world's factory", achieving the feat of lifting more people out of poverty than has ever been seen in the world. Looking back at history, the Chinese Communist Party has led the Chinese people through about 30 years of new democratic revolution, 30 years of socialist construction, and 30 years of socialist reforms (Yan, 2017: p. 175). During this process, the Chinese have washed away the century of humiliation of Western aggression against China since the Opium War in 1840, and are ushering in a new era of the great rejuvenation of the Chinese nation with the "two centenary goals" as the main content. At the 19th National Congress of the Communist Party of China held in 2017, the Communist Party of China clearly stated that in the 30 years after 2020, it must complete the goal of constructing a modern and powerful socialist country in two steps, by which time the Chinese will have truly realized the Chinese dream of the great rejuvenation of the Chinese nation.

Sima Qian said in "Records of the Grand Historian: Astronomy": "A man's destiny is a small change at the age of 30 , a moderate change in 100 years, and a big change in 500 years; for a country, the numbers three and five need to be focused on." (Sima, 2013: p. 1601). It is difficult for us to understand that the ancients summed up the laws of history by observing astronomy and geography. There may have been many things that violated science. However, our country experienced the century of humiliation from the Opium War of 1840 to the founding of the People's Republic of China in 1949, and is now striving to achieve the second centenary goal of building a modern and powerful socialist country by 2049. In this century, we have gone through about 30 years of construction and 30 years of reform, and we have clearly planned our goals for the next 30 years. What China is starting now is not just another small change in 30 years, nor just a moderate change in the second century, it will surely accumulate into a global 500 -year big change, that is, the Chinese people will, under the guidance of the great banner of Xi Jinping's thoughts on socialism with Chinese characteristics in the new era, not only once again move toward a close match and "relative balance" with developed Western capitalist countries economically, (Han, 2011: p. 249) but even surpass the developed Western capitalist countries in an all-round way.

Looking back on China's history from standing up, getting rich, and ushering in a bright future, China has surpassed traditional capitalism and socialism and formed socialism with Chinese characteristics that actively combines capitalism and socialism. If we say that the drastic changes in Eastern Europe and the disintegration of the Soviet Union from 1989 to 1991 have declared that Soviet-style socialism can no longer meet the needs of the development of the times, then the 
financial crisis that broke out in 2008 and the subsequent global economic recession proved that the American model of capitalism was also abandoned by the development of the times. Today, not many people are willing to return to living under the Soviet model of socialism, and of course it is impossible to rebuild the Soviet model of socialism. Likewise, neoliberalism has fallen into disrepute, and even in the West, not many people are willing to accept laissez-faire capitalism. The rapid development of China in the past years of Reform and Opening Up has forced the world to begin to carefully examine China's successes. Regardless of whether the West calls it the "Chinese Model" or the "Beijing Consensus", socialism with Chinese characteristics has clearly been regarded as an innovation different from Soviet model socialism and American model capitalism.

Soviet-style socialism and American-style capitalism were the banners of the struggle between the two camps after the end of the Second World War. In the final analysis, China's success was to break away from the struggle between capitalism and socialism, and to take a new modernization path in line with China's national conditions. In 1992, Deng Xiaoping made it clear that the "three favorable standards" were "whether it is conducive to the development of a socialist society's productive forces, whether it is conducive to enhancing the overall national strength of a socialist country, and whether it is conducive to improving the people's living standards" to judge questions of "capitalism" or "socialism", (Deng, 1993: p. 327) later becoming the standard used by the Party to measure the success or failure of all work. The current increases in China's overall national strength, productivity, and people's living standards are the result of hard work in accordance with the standards set by Deng Xiaoping.

Therefore, the key to China's development from standing up, getting rich, and getting stronger is determining a good development concept and measurement standard. At the Second Plenary Session of the Fifth Plenary Session of the Eighteenth Central Committee of the Communist Party of China, Xi Jinping clearly pointed out that "an idea is the forerunner of action, and certain development practices are guided by certain development concepts"; "whether development concepts are right, is fundamentally determined by the effectiveness of development and even success or failure"; "If the development concept is right, the goals and tasks will be set, and the policies and measures will be set." (Xi, 2017: p. 197). The "Proposals of the Central Committee of the Communist Party of China on Formulating the Thirteenth Five-Year Plan for National Economic and Social Development" proposes to adhere to the development concepts of innovation, coordination, greenness, openness, and sharing. This is the standard for measuring the success or failure of China's economic development in the future. Leading China's economic development under the new normal with a new development concept, China's economic development will surely be elevated to a new level.

China never thought that one day it would engage in a hegemonic military struggle with the United States, and it has already stepped out of the Cold War 
mentality of an ideological "Cold War". The current so-called "trade war", "technology war" and "military contest" between China and the United States are, in the final analysis, the consequences of the "Cold War" thinking of the United States. China's innovative, coordinated, green, open, and shared new development concepts and new plans for building a community with a shared future for mankind make up China's wisdom in contributing to the realization of win-win cooperation and common development among all countries in the world. When Deng Xiaoping met with the economic and trade delegation of the Government of the Democratic Republic of Madagascar in 1977, he said: "By the time the four modernizations have been realized and the national economy has developed, we may contribute a little more to mankind, especially to the third world." "As a socialist country, China will always belong to the third world and will never be able to seek hegemony." "This is a foreign policy formulated by Chairman Mao Zedong and Premier Zhou Inlay, and we must use it to educate future generations." (Deng, 1993: p. 112). So far, although China has risen to become the second largest economy in the world, it has not taken any military actions in the process other than sending peacekeeping troops or conducting rescue operations. As for China's total economic output reaching number two in the world, this has been an unprecedented peaceful rise, and it has crossed the so-called "Thucydides trap."

On September 28, 2015, Xi Jinping delivered a speech at the 70th United Nations General Assembly and proposed that through "establishing a partnership of equal treatment, mutual consultation and mutual understanding", "creating fairness and justice, building a shared security model" and "seeking open, innovative, inclusive and mutually beneficial development prospects", "promoting harmonious but different, inclusive cultural exchanges", "building an ecosystem that respects nature and green development", "joining hands to build new partners through cooperation and win-win, building a community with a shared future for mankind." (Xi, 2017: pp. 523-526). On January 17, 2017, in a keynote speech delivered at the opening ceremony of the 2017 Annual Meeting of the World Economic Forum, it was stated that "economic globalization is an objective requirement for the development of productive forces and the inevitable result of technological progress, not created by anyone or any country. Countries should "adhere to being innovation-driven and create a dynamic growth model", "adhere to coordination and linkage, create an open and win-win cooperation model", "adhere to advancing with the times and create a fair and reasonable governance model", and "adhere to fairness and tolerance to create a balanced and inclusive development model"; "share the responsibilities of the times and jointly promote global development" (Xi, 2017: pp. 480-482). On January 18, 2017, Xi Jinping again delivered a speech at the United Nations headquarters in Geneva, saying, "What's the matter with the world? What do we do? This is a question that the whole world is thinking about"; "China's plan is to build a community with a shared future for mankind and achieve win-win sharing" (Xi, 2017: p. 539).

The Chinese people missed the era of capitalist industrialization because of 
China's closed doors, but in the era of resistance to imperialist wars and socialist revolutions, China stood up and got rich through revolution and reform. In the new era of world multi-polarization, economic globalization, cultural diversification, and social informatization, Xi Jinping's thoughts on socialism with Chinese characteristics in the new era adhere to the new development concepts of innovation, coordination, greenness, openness, and sharing, and promote the construction of a community with a shared future for mankind. It will certainly guide the Chinese people to realizing the Chinese dream of the great rejuvenation of the Chinese nation. It will also provide new choices for countries and peoples in the world who wish to accelerate development and maintain their independence, and contribute Chinese wisdom and Chinese solutions to solving common problems of mankind. China will once again become an advanced civilization that leads the progress of human civilization. In this regard, both for China and the world, this is a major change unseen in 500 years.

\section{Conclusion}

So what good lessons can we learn from the last 500 years? Most Chinese will agree with Ray Dalio's big cycle theory about empire's rise and decline according their 5000 years of history, and believe China can be rejuvenated one day. The most valuable lessons from history are to concern about the dangers when being safe, or the coming decline when at the top, and to make efforts for the rejuvenation when in decadence. To keep at the top for as long as possible and to revive after falling, fighting war is not good choice, just like an old man and young child's fighting with the strong ones. Although wars could be destined for keeping and rising powers, what makes the keeping power's power kept and the rising power's rising realized is to learn from the rising history. The old China did fight again and again but lost wars again and again until it turn to learn from the socialism Soviet to stand up. Anyway, China did not win much from the cold war between the socialism Soviet and the capitalism America until it learn from the capitalism America while keeping what is good from the socialism Soviet. So China's re-rising is not a story of fighting to win, but learning to win. For Ray Dalio, what is destined is not war, but the cycle of rising and falling, like a human being, so the good lesson from the history is not to fight war for power, but to learn for rejuvenation. By combing through the 500-year history of socialism and capitalism that have coexisted and competed with each other, this paper believes that China did come to its rejuvenation after centuries' learning for the West, but China needed to keep learning from the West to keep rising, and the West also needs to learn from China to keep powerful. To learn from each other is the light-tower of hope which human beings can reach, and to fight for power is Thucydides's Trap which human beings cannot escape.

\section{Acknowledgements}

This paper is related to "rejuvenation and co-sharing, the Research on What Communism means for the Communist Party of China" supported by National So- 
cial Science Fund of China (No. L19N500010), I am thankful for its endowment.

\section{Conflicts of Interest}

The authors declare no conflicts of interest regarding the publication of this paper.

\section{References}

Allison, G. (2018). Destined for War: Can America and China Escape Thucydides's Trap? New York, NY: Mariner Books.

Belden, J. (1980). China Shakes the World(Chinese ed., pp. 323-324). Beijing: Beijing Press.

Dalio, R. (2020). The Changing World Order, Where We Are and Where We're Going, Introduction. https://www.linkedin.com/pulse/changing-world-order-ray-dalio-1f/

Deng, X. P. (1993). Dengxiaoping’s Selected Wrtings. No.3, Beijing: People’s Publishing House.

Goldstone, J. (2010). Why Europe? The Rise of the West in World History, 1500-1850 (Chinese ed., p. 5). Hangzhou: Zhejiang University Publishing House.

Han, Y. H. (2011). Who Will Write the History: China and the World from 1500 (p. 249). Place: Nine States Press.

Huntington, S. P. (2011). The Clash of Civilizations and the Remaking of World Order. New York, NY: Simon \& Schuster.

Kocka, J. (2017). Geschichte des Kapitalismus (Chinese ed., p. 26). Shanghai: Wenhui Press.

Liang, Q. C. (2017). The Story of Lihongzhang (pp. 61-63). Beijing: Commerce Press International.

Mao, Z. D. (1991). Maozedong’s Selected Writings: Book 4. Beijing: People Press.

Mao, Z. D. (1999). Maozedong's Writings Collection: Book 6. Beijing: People Press.

Marx \& Engles (1995). Marx and Engles' Selected Wrtings: Book 1. Beijing: People Press.

Micklethwait, J., Wooldridge, A., Via, H., \& Virginia, H. (2020). The Wake-Up Call: Why the Pandemic Has Exposed the Weakness of the West (pp.10-11). New York, NY: HarperVia.

Morris, I. (2014). Why the West Rules (Chinese ed., p. 277). Beijing: Citic Press.

Qian, M. (1996). The Outline of National History (pp. 878-879). Beijing: Commerce Press.

Sima, Q. (2013). The History Writings: Book 4 (p. 1601). Beijing: Zhonghua Book Company.

Stavirianos, L. S. (2004). A Global History: From Prehistory to the 21st Centur (p. 396). Beijing: Peking University Press, 396.

Xi, J. P. (2017). The Governance of China, Book 2. Beijing: Foreign Language Press.

Yan, Y. L. (2017). China's Way: Four 30-Years Exploreing of Socialism (p. 175). Hangzhou: Zhejiang People Press. 